\title{
II. THE SIMULTANEOUS MEASUREMENT OF EXCHANGEABLE BODY SODIUM AND POTASSIUM UTILIZING ION EXCHANGE CHROMATOGRAPHY
}

\author{
By WALTER L. ARONS, ROBERT J. VANDERLINDE, AND A. K. SOLOMON \\ (From the Biophysical Laboratory and the Department of Medicine of the Harvard Medical \\ School and the Medical Service of the Peter Bent Brigham Hospital, Boston, Mass.)
}

(Submitted for publication February 8, 1954 ; accepted March 3, 1954)

A technique based on the isotope dilution principle for the measurement of exchangeable body sodium in man has been devised and evaluated by Forbes and Perley (1) and Miller and Wilson (2), and a similar technique for exchangeable body potassium has been developed by Corsa, Olney, Steenburg, Ball, and Moore (3). Once the individual techniques for the measurement of exchangeable body sodium and potassium had been devised, the desirability of carrying out these measurements simultaneously became apparent because of the important biochemical inter-relationships that have been pointed out between these two alkali metals (4-6). Since the metabolic state of a patient may vary considerably during even a relatively short period, single exchangeable body sodium and potassium measurements carried out several days apart are not a satisfactory substitute for simultaneous measurements.

Such simultaneous measurements, based on the isotope dilution principle, require at present the separation of sodium from potassium prior to the radioactivity determinations. James, Brooks, Edelman, Olney, and Moore (7) have described a technique for these measurements in which classical chemical methods are used to separate the electrolytes. In the present study we have made use of ion exchange chromatography (8) for the separation. At the outset, our primary concern has been with the reproducibility of this technique for the simultaneous measurements of exchangeable body sodium and potassium in normal young adults.

\section{"Exchangeability" of sodium and potassium}

Twenty-four hours has been chosen by previous investigators $(1-3,7)$ as a satisfactory and convenient equilibration period. Estimated values in man indicate that approximately 82 per cent (1) of the total body sodium and 90 to 95 per cent of the total body potassium (3) are exchangeable in twenty-four hours. These measurements must be considered as preliminary since their accuracy depends on an exact knowledge of rates of electrolyte exchange in all areas of the body, data which are not yet completely available in man. In the case of sodium, bone and brain constitute areas of slow exchange $(1,2,9)$, while in the case of potassium, red cell, brain, and bone exchange less rapidly than do other regions of the body $(3,10)$. Even though the measurement of exchangeable sodium and potassium of the body does not correspond to the total body content of these elements, it does furnish an index of total body sodium and potassium which probably varies directly with total body electrolyte content.

\section{EXPERIMENTAL METHOD}

\section{a) General outline}

Known amounts of radioactive sodium $\left(\mathrm{Na}^{2 \mathrm{~N}}\right)$ and of radioactive potassium $\left(\mathrm{K}^{43}\right)$ are injected intravenously. After a twenty-four hour equilibration period, a blood sample is drawn and sodium and potassium radioactivity and concentration (i.e., specific activity) of the proteinfree serum supernatant are determined. We have described in detail in Part I (8) the use of a sulfonic acid cation exchange resin, Dowex 50, to effect the separation of $\mathrm{Na}^{3}$ and $\mathrm{K}^{*}$ in order to measure their radioactivity separately as is required for these determinations by our method. Once the sodium and potassium fractions are separated, their respective specific activities ( $\left.\frac{\text { counts/min. }}{\mathrm{mEq} \text {. }}\right)$ are determined. The exchangeable body sodium and potassium are then calculated from these data and from the $\mathrm{Na}^{\mathrm{NA}}$ and $\mathrm{K}^{\mathrm{an}}$ activities in a 24-hour urine sample according to the following standard isotope dilution equation:

(1)

$$
E=\frac{C_{i}-C_{0}}{\left[C_{i}\right] /[E]}
$$


in which $E$ = amount of exchangeable body electrolyte in $\mathbf{m E q}$.

$C_{i}=$ total amount of injected radioisotope in counts per min.

$\mathrm{C}_{\mathbf{0}}=$ total amount of excreted radioisotope (24hour period) in counts per min.

$\left[\mathrm{C}_{\ell}\right]=$ concentration of radioisotope found in the body fluid (serum in our case) in counts per min. per liter.

$[E]=$ concentration of naturally occurring electrolyte in body fluid in $\mathrm{mEq}$. per $\mathrm{L}$. $\left[\mathrm{C}_{\ell}\right] /[\mathrm{E}]=$ specific activity.

\section{b) Preparation of radioactive material}

$\mathrm{Na}^{\mathrm{N}}$ and $\mathrm{K}^{\mathrm{s3}}$ were obtained from the Atomic Energy Commission at the Brookhaven National Laboratory in the form of the carbonate, converted to the corresponding chloride salt by the addition of $1 \mathrm{~N}$ hydrochloric acid, and the solutions adjusted to $\mathrm{a} \mathrm{pH}$ of 7 . These salts were in turn diluted in distilled water to a sodium concentration of approximately $15 \mathrm{mEq}$. per $\mathrm{L}$. and to a potassium concentration of about $155 \mathrm{mEq}$. per $\mathrm{L}$. and assayed for activity against a uranium standard. The radioactive solutions were then further diluted in isotonic saline for injection purposes so that the $50 \mathrm{ml}$. injected would contain approximately $125 \mu \mathrm{c}$. of $\mathrm{Na}^{24}$ and $250 \mu \mathrm{c}$. of $\mathrm{K}^{43}$. The cation concentrations of the final solutions for injection were approximately 155 and $3 \mathrm{mEq}$. per $\mathrm{L}$. of sodium and potassium, respectively. These solutions were then neutralized with $0.1 \mathrm{~N} \mathrm{NaOH}$ to a $\mathrm{pH}$ of 7.4 and sterilized in an autoclave.

\section{c) Preparation of resin}

The Dowex 50 resin, 12 per cent cross-linked, minus 400 mesh, and in the hydrogen cycle was obtained from Dow Chemical Company. 1 Resin columns were made up in glass tubing $1.3 \mathrm{~cm}$. in diameter and rested on sintered glass filters of medium porosity. The resin was suspended in water, poured into the glass column until the particles had settled to a height of $8 \mathrm{~cm}$. and then capped with glass wool. To insure complete freedom of the resin from traces of sodium and potassium all resin columns were washed before use with $300 \mathrm{ml}$. of $3 \mathrm{~N}$ hydrochloric acid followed by distilled water until the eluate was neutral to litmus. By means of this procedure the resin could be reused an indefinite number of times, care being taken to resuspend the resin and repack the column before each separation.

\section{d) Measurement of radioactivity and electrolyte con-} tration

The radioactivity was measured by use of a dipcounter described by Solomon and Estes (11) which had ben placed in a special stand designed by Dr. C. V. Robinson. This counter had a glass window thickness of

1 We should like to express our thanks to the Dow Chemical Company for their kindness in supplying resin and their advice in its use. about $30 \mathrm{mg}$. per $\mathrm{cm}^{2}$. and could accommodate $8 \mathrm{ml}$. samples. The coefficient of variation of sets of 12 identical samples counted with this equipment was 2 per cent. The sodium eluate fraction was counted in duplicate, each sample for 10,000 counts, requiring about seven minutes apiece. Because of the low concentration of serum potassium, the potassium fraction was counted to 5000 counts requiring about 20 minutes. Potassium samples were counted in duplicate whenever possible. Duplicate standard solutions of $\mathrm{Na}^{24}$ (dilution $5: 1000$ ) and $\mathrm{K}^{4}$ (dilution 1:1000) were made up from the solutions prepared for injection. These were each counted in triplicate to 10,000 counts each. An end-window Geiger tube (2.5 mg. per $\mathrm{cm}^{2}$. window) was used for urine counting. All data were corrected for background counts, dead time loss when necessary, and for radioactive decay.

Sodium and potassium concentrations in the eluate fractions were determined in duplicate on a Baird Associate Flame Photometer utilizing an internal standard. To avoid sodium and potassium contamination, all glassware and tubing was rinsed before use with dilute hydrochloric acid and distilled water. Sodium and potassium recovery experiments showed that the error of each flame determination was of the order of 1.5 per cent.

\section{e) Injection, and sodium and potassium separation}

Fifty $\mathrm{ml}$. syringes for injection of radioactivity were calibrated by weighing the amount of water they would deliver and making the appropriatè temperature correction. All injections were of $50 \mathrm{ml}$. volume to minimize the error of injection which was found to be 0.3 per cent. They were administered intravenously via the tubing of a 5 per cent dextrose in water infusion. Intravenous injection through the tubing of an infusion was found to be less subject to mishap than direct intravenous injection of volumes as large as $50 \mathrm{ml}$. Approximately $125 \mu_{\mathrm{c}}$. of $\mathrm{Na}^{23}$ and $250 \mu \mathrm{c}$. of $\mathrm{K}^{23}$ were injected into the subject from separate syringes.

The whole body radiation resulting from this radioactivity computed by the method of Marinelli, Quimby, and Hine (12), is 0.45 equivalent roentgens. Since this dosage was used twice or, rarely, three times, several weeks apart, the total body radiation administered was considered within tolerance limits.

After a twenty-four hour equilibration period, $50 \mathrm{ml}$. of blood was drawn from the subject following an overnight fast. All urine passed during this 24-hour period was also collected. After the 24-hour blood sample was drawn, the serum was separated and the serum proteins precipitated with $15 \mathrm{ml}$. of 10 per cent trichloracetic acid (C.P.). The precipitate was then spun down at $1280 \mathrm{G}$ for 10 minutes and the clear supernatant added to the resin column at a rate of $1.5 \mathrm{ml}$. per minute. The precipitate was then washed with $10 \mathrm{ml}$. of 10 per cent trichloracetic acid; after centrifugation, this supernatant was also added to the resin column. Twenty-six hundredths $\mathrm{N}$ hydrochloric acid (C.P.) was then passed through the column at a rate of $0.74 \mathrm{ml}$. per min. The elutriant was drawn through the column by a pump 
described in Part I (8) which insured a uniform rate of flow through the system. The pump could regulate the flow through four columns in parallel, thus making possible four simultaneous separations.

After the initial $80 \mathrm{ml}$. of eluate had been discarded because it contained no electrolyte, the remainder of the eluate was collected in three fractions by volume measurement. 2 The first $120 \mathrm{ml}$. fraction contained the sodium of the serum, the next $60 \mathrm{ml}$. made up the valley between the peaks, while the last $80 \mathrm{ml}$. contained the potassium fraction. In order to collect the potassium fraction as quickly as possible, we routinely increased the normality of the eluting acid to $2.6 \mathrm{~N}$ and doubled the rate of flow before eluting the last $80 \mathrm{ml}$. Under these conditions, the total time necessary for collection of all samples was approximately six hours. The data given in Part I (8) support the choice of these volume relationships and show that the curves are regularly reproducible.

Each of the three fractions was then evaporated down to a few ml., made up to $10 \mathrm{ml}$. with distilled water and mixed thoroughly. Eight ml. were then transferred to the dip-counter for radioactivity measurements. After counting, the same samples were analyzed for sodium and potassium concentration by flame photometry. Initially, sodium and potassium concentrations were determined on all three fractions. No determinations, however, other than the sodium analysis of the sodium fraction and the potassium analysis of the potassium fraction are necessary for the calculation of exchangeable body sodium and potassium, respectively; the other concentration measurements serve merely as checks on possible cross-contamination of the samples. Since we have never found measurable potassium in the sodium fraction, this measurement, along with flame analysis of the valley fraction, can be abandoned. Analysis of the potassium fraction for sodium is the only determination for crosscontamination that need be carried out.

\section{f) Measurement of excreted radioactivity}

Since the 24-hour urine sample usually contains only about 5 per cent of the injected dose of $\mathrm{Na}^{34}$ (1) and $\mathrm{K}^{\text {s2 }}$ (3), it was not necessary to use the resin column to make an accurate measurement of these radioisotopes in the urine. For the urine measurements we have made use of a differential absorption technique with an aluminum absorber as suggested by others (7). Since the beta rays of $\mathrm{K}^{\mathrm{s}}$ are of higher energy than those of $\mathrm{Na}^{\mathrm{N}},{ }^{3}$ the 166 mg. per $\mathrm{cm}^{3}$. aluminum absorber we utilized transmits 72 per cent of the radiation from $\mathrm{K}^{12}$ and only 21 per cent

2 A simple modification of a two-pan laboratory balance made it possible to collect each fraction automatically. The collection flask was placed on one pan of the balance, and the tares and weights adjusted so that the balance would come to equilibrium when the desired volume had been collected. A mercury switch which controlled the mechanical pump was attached to the cross-beam of the balance, so that the circuit to the pump was broken as soon as the balance came to equilibrium.

3 See footnote 1 in Part I (8). of the radiation from $\mathrm{Na}^{2}$. Urine samples were made up in triplicate, by evaporating $1 \mathrm{ml}$. of urine in aluminum planchets under an infra red lamp and were counted under an end-window Geiger tube with and without the 166 mg. per $\mathrm{cm}^{2}$. absorber in place and with constant geometry. The counting rate of the $\mathrm{Na}^{24}$ and $\mathrm{K}^{\mathbf{2}}$ in the urine samples could be obtained by solving the following simultaneous equations:

$$
\begin{gathered}
\mathrm{S}=\mathrm{Na}+\mathrm{K} \\
\mathrm{s}=0.21 \mathrm{Na}+0.72 \mathrm{~K}
\end{gathered}
$$

where $\mathrm{S}=$ counts per min. of planchets without absorber ; $\mathrm{s}=$ counts per min. of planchets with absorber; $\mathrm{Na}=$ counts of radioactive sodium; and $\mathrm{K}=$ counts of radioactive potassium.

To calculate the total 24-hour urine activity, it is necessary to correct the end-window counts to dip-tube counts; this is accomplished by measuring the relative efficiencies of the two counters for $\mathrm{Na}^{24}$ and $\mathrm{K}^{43}$. The over-all error in the urine method is between 3 and 5 per cent which is less than 0.3 per cent of the injected dose under all conditions of urine electrolyte composition.

The amounts of sodium and potassium lost in feces and through the skin $(2,13-16)$ are so small (totalling about 0.5 per cent of the injected dose) as not to have any significant effect on the body electrolyte measurements under most conditions. Under extreme conditions of diarrhea or sweating, however, it is possible that significant amounts of radioactivity could be lost via these routes. We have made no attempt to correct for this small electrolyte loss.

\section{RESULTS AND DISCUSSION}

\section{Reproducibility of the method}

In order to determine the reproducibility of the method, exchangeable body sodium and potassium measurements were repeated in the same normal young adult subjects at intervals of one to two weeks and in two instances several months apart. In a single subject, simultaneous measurements were made on three occàsions. Thirteen simultaneous body sodium and potassium measurements were carried out in six patients. The data are presented in Table I. It is assumed that these normal subjects on normal diets and activities were in electrolyte balance during the experimental period.

The difference between pairs of exchangeable body electrolyte measurements are expressed as the difference of these measurements from their means in per cent of the mean. In the case of sodium, the differences vary from 0.7 to 3.8 per cent and in the case of potassium the differences range from 0.3 to 2.0 per cent. Coefficients of variation for a single determination determined from these 
TABLE I

Reproducibility of simultaneous exchangeable body sodium and potassium measurements

\begin{tabular}{|c|c|c|c|c|c|c|c|c|}
\hline Subject & Date & Sex & $\begin{array}{c}\text { Age } \\
\text { (yrs.) }\end{array}$ & $\begin{array}{l}\text { Wt. } \\
\left(\boldsymbol{K}_{\mathbf{g}}\right)\end{array}$ & $\begin{array}{c}\text { Exchangeable } \\
\text { body } \mathrm{Na} \\
\left(m E_{q}\right)\end{array}$ & $\begin{array}{l}\text { Differences } \\
\text { from mean } \\
\text { as \% of } \\
\text { mean }\end{array}$ & $\begin{array}{c}\text { Exchangeable } \\
\text { body } \mathbf{K} \\
\left(m E_{q .}\right)\end{array}$ & $\begin{array}{l}\text { Differences } \\
\text { from mean } \\
\text { as \% of } \\
\text { mean }\end{array}$ \\
\hline R. K. & $\begin{array}{l}5 / 8 / 53 \\
5 / 15 / 53\end{array}$ & $\mathbf{M}$ & 29 & $\begin{array}{l}66.6 \\
67.3\end{array}$ & $\begin{array}{l}2,978 \\
2,917\end{array}$ & \pm 1.0 & $\begin{array}{l}3,424 \\
3,487\end{array}$ & \pm 0.9 \\
\hline D. F. & $\begin{array}{l}3 / 19 / 53 \\
3 / 26 / 53 \\
5 / 7 / 53\end{array}$ & $\mathbf{M}$ & 29 & $\begin{array}{l}68.2 \\
68.3 \\
68.2\end{array}$ & $\begin{array}{l}3,022 \\
2,853 \\
2,854\end{array}$ & $\begin{array}{l}+3.8 \\
-1.9 \\
-1.9\end{array}$ & $\frac{3,539}{3,430}$ & \pm 1.5 \\
\hline F. $\mathbf{M}$. & $\begin{array}{l}4 / 8 / 53 \\
6 / 10 / 53\end{array}$ & $\mathbf{M}$ & 29 & $\begin{array}{l}73.6 \\
73.4\end{array}$ & $\begin{array}{l}3,150 \\
3,105\end{array}$ & \pm 0.7 & $\begin{array}{l}3,612 \\
3,705\end{array}$ & \pm 1.3 \\
\hline E. G. & $\begin{array}{l}4 / 1 / 53 \\
4 / 15 / 53\end{array}$ & $\mathbf{F}$ & 21 & $\begin{array}{l}48.5 \\
47.6\end{array}$ & $\begin{array}{l}1,875 \\
1,986\end{array}$ & \pm 2.9 & $\begin{array}{l}2,161 \\
2,148\end{array}$ & \pm 0.3 \\
\hline M. H. & $\begin{array}{l}4 / 8 / 53 \\
4 / 15 / 53\end{array}$ & $\mathbf{F}$ & 21 & $\begin{array}{l}51.8 \\
52.2\end{array}$ & $\begin{array}{l}2,139 \\
2,073\end{array}$ & \pm 1.5 & $\begin{array}{l}2,365 \\
2,274\end{array}$ & \pm 2.0 \\
\hline \multirow[t]{2}{*}{ C. W. } & $\begin{array}{l}5 / 8 / 53 \\
5 / 15 / 53\end{array}$ & $\mathbf{F}$ & 22 & $\begin{array}{l}50.6 \\
50.9\end{array}$ & $\begin{array}{l}2,102 \\
2,068\end{array}$ & \pm 0.8 & $\begin{array}{l}2,007 \\
2,078\end{array}$ & \pm 1.8 \\
\hline & & & & \multicolumn{2}{|c|}{ Coefficient of Variation } & $\pm 2.6 \%$ & & $\pm 2.0 \%$ \\
\hline
\end{tabular}

data are \pm 2.6 per cent and \pm 2.0 per cent for the exchangeable body sodium and potassium measurements, respectively, indicating a high degree of reproducibility. The predicted standard deviation of the method as determined from the analytic sum of the measured errors of injection, flame analyses, and radioactivity measurements is \pm 2.5 per cent of the exchangeable electrolyte value, agreeing well with the reproducibility observed. These figures are in close agreement with those obtained by Corsa, Olney, Steenburg, Ball and Moore (3) in the single exchangeable body potassium measurement technique. These investigators have estimated that a difference of \pm 4 per cent between determinations is significant (approximately two times the coefficients of variation obtained by us for a single determination). It should be pointed out, however, that the coefficient of variation for a difference between determinations is appreciably greater than the coefficient of variation for any single measurement, as given in Table I. In the present case the coefficients of variations for differences are 3.7 per cent for sodium and 2.8 per cent for potassium." Consequently, we consider that differences of \pm 7.5 per cent for sodium and $\pm \mathbf{5 . 5}$ per cent for potassium

- Coefficient of variation (for differences) $=$

$$
\sqrt{(\mathrm{CV})^{3}+(\mathrm{CV})^{2}}
$$

where $C V=$ coefficient of variation for a single reading. (approximately two times the coefficient of variation for the differences) represent conservative valid criteria for significant differences between measurements.

\section{Urinary excretion}

In our normal subjects the 24-hour excretion of $\mathrm{Na}^{24}$ varies from 3.3 to 11.8 per cent of the injected dose with a mean of 6.5 per cent as is shown in Table II. The 24-hour excretion of $\mathrm{K}^{\mathbf{4 2}}$ varies from 2.1 to 7.2 per cent with a mean of 3.6 per cent. These values are of the same magnitude as those reported previously by others $(1-3,17)$. As these investigators have also noted, the amount of $\mathrm{Na}^{24}$ and $\mathrm{K}^{42}$ excreted in the urine varies directly with the total amount of sodium and potassium excreted, as is suggested by the data in Table II where mean excretion values for natural sodium

TABLE II

Twenty-four hour excretion of radioactive and natural sodium and potassium *

\begin{tabular}{|c|c|c|c|c|}
\hline & $\underset{\text { excreted }}{\% \mathrm{Na}^{2}}$ & $\begin{array}{c}\% \text { body } \\
\text { Na } \\
\text { excreted }\end{array}$ & $\underset{\text { excreted }}{\% \mathrm{~K}}$ & $\begin{array}{c}\% \text { body } \\
\text { excreted }\end{array}$ \\
\hline $\begin{array}{l}\text { Mean } \\
\text { Range }\end{array}$ & $\begin{array}{c}6.5 \\
3.3^{-11.8}\end{array}$ & $\begin{array}{c}5.7 \\
2.0-9.0\end{array}$ & $\begin{array}{c}3.6 \\
2.1-7.2\end{array}$ & $\begin{array}{c}2.5 \\
1.5-4.2\end{array}$ \\
\hline
\end{tabular}

* $\mathrm{Na}^{24}$ and $\mathrm{K}^{*}$ excretions are expressed as percentage of administered dose while stable $\mathrm{Na}$ and $K$ in the urine are expressed as percentage of the corresponding exchangeable body electrolyte value. These urinary data are derived from sixteen combined measurements in eleven patients. 
TABLE III

Exchangeable body sodium and potassium of normal young adults

\begin{tabular}{|c|c|c|c|c|c|c|c|c|c|}
\hline Subject & Sex & $\begin{array}{c}\text { Age } \\
\text { (yrs.) }\end{array}$ & $\begin{array}{c}\text { Height } \\
(\mathrm{cm.)}\end{array}$ & $\begin{array}{c}\text { Weight } \\
\left(K_{\text {G. }}\right)\end{array}$ & $\underset{\left(m E_{q} .\right)}{N_{a}}$ & $\underset{\left(m E q . / K_{8 .}\right)}{N a,}$ & $\underset{\left(m E_{q .}\right)}{\mathbf{K}_{\mathbf{g}}}$ & 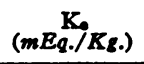 & $\mathrm{Na}_{0} / \mathrm{K}_{0}$ \\
\hline $\begin{array}{l}\text { D. F. } \\
\text { A. K. } \\
\text { F. M. } \\
\text { R. K. } \\
\text { W. G. } \\
\text { M.S. } \\
\text { E. G. } \\
\text { M. H. } \\
\text { M. B. } \\
\text { C. W. } \\
\text { V. D. } \\
\text { C. J. }\end{array}$ & $\begin{array}{l}\mathbf{M} \\
\mathbf{M} \\
\mathbf{M} \\
\mathbf{M} \\
\mathbf{M} \\
\mathbf{F} \\
\mathbf{F} \\
\mathbf{F} \\
\mathbf{F} \\
\mathbf{F} \\
\mathbf{F} \\
\mathbf{F}\end{array}$ & $\begin{array}{l}29 \\
27 \\
29 \\
29 \\
26 \\
26 \\
21 \\
21 \\
25 \\
22 \\
23 \\
27\end{array}$ & $\begin{array}{l}180 \\
170 \\
176 \\
170 \\
174 \\
161 \\
153 \\
165 \\
159 \\
165 \\
163 \\
169\end{array}$ & $\begin{array}{l}68.2 \\
68.0 \\
73.4 \\
66.6 \\
72.5 \\
51.6 \\
48.5 \\
51.8 \\
59.2 \\
50.6 \\
58.5 \\
54.9\end{array}$ & $\begin{array}{l}3,022 \\
2,899 \\
3,105 \\
2,978 \\
2,969 \\
2,002 \\
1,875 \\
2,139 \\
1,999 \\
2,102 \\
2,127 \\
2,626\end{array}$ & $\begin{array}{l}44.3 \\
42.6 \\
42.3 \\
44.7 \\
40.9 \\
38.8 \\
38.7 \\
41.3 \\
33.8 \\
41.5 \\
36.4 \\
47.8\end{array}$ & $\begin{array}{l}3,539 \\
3,709 \\
3,705 \\
3,424 \\
3,407 \\
1,994 \\
2,161 \\
2,365 \\
2,103 \\
2,007 \\
2,663 \\
2,629\end{array}$ & $\begin{array}{l}\mathbf{5 1 . 9} \\
54.5 \\
50.5 \\
51.4 \\
47.0 \\
38.6 \\
45.0 \\
45.4 \\
35.5 \\
39.7 \\
45.5 \\
47.9\end{array}$ & $\begin{array}{l}0.85 \\
0.78 \\
0.84 \\
0.87 \\
0.87 \\
1.00 \\
0.87 \\
0.90 \\
0.95 \\
1.10 \\
0.80 \\
1.00\end{array}$ \\
\hline
\end{tabular}

and potassium are expressed as a percentage of the exchangeable body sodium and potassium for comparison with the $\mathrm{Na}^{24}$ and $\mathrm{K}^{42}$ excretion data. These excretion data indicate a relatively rapid equilibration of these radioisotopes with their miscible body pools so that excretion of both radioactive and stable isotopes parallel each other.

\section{Normal values}

The data obtained in our group of normal young adults between the ages of 20 and 30 years may be used for comparison with those of other investigators. The subjects, chiefly nurses and doctors, were on their usual diets and activities during the experimental period. The values obtained by us are presented in Table III, and are expressed in terms of body weight ( $\mathrm{mEq}$. per $\mathrm{Kg}$.) in agreement with the practice of previous investigators $(1-3,17)$. However, when body sodium and potassium are expressed in this fashion wide ranges of normal values are found even within the confines of a relatively homogeneous group of the same sex and age, because of individual variations in the body content of fat (electrolyte poor) and muscle (potassium rich). Nonetheless it can be seen from Table IV that our values in a limited series of exchangeable sodium measurements (mean values $43.9 \mathrm{mEq}$. per $\mathrm{Kg}$. for males and $39.7 \mathrm{mEq}$. per $\mathrm{Kg}$. for females) and exchangeable potassium measurements (mean values $51.1 \mathrm{mEq}$. per $\mathrm{Kg}$. for males and $42.4 \mathrm{mEq}$. per $\mathrm{Kg}$. for females) agree well with those of other investigators,

TABLE IV

Exchangeable body sodium and potassium in normal subjects

\begin{tabular}{|c|c|c|c|c|}
\hline \multirow[b]{2}{*}{ Investigator } & \multicolumn{2}{|c|}{$\begin{array}{c}\text { Exchangeable body sodium* } \\
\left(m E q . / K_{g}\right)\end{array}$} & \multicolumn{2}{|c|}{$\begin{array}{l}\text { Exchangeable body potassium* } \\
\left(m E_{Q .} / K_{\varepsilon .}\right)\end{array}$} \\
\hline & Males & Females & Males & Females \\
\hline $\begin{array}{l}\text { Corsa, Olney, Steenberg, Ball, and } \\
\text { Moore (3) }\end{array}$ & & & $\begin{array}{c}46.3 \dagger \\
(37.0-57.1)\end{array}$ & \\
\hline Forbes and Perley (1) & $\begin{array}{c}41.9 \\
(32.3-54.1)\end{array}$ & $\begin{array}{l}39.5 \\
(35.7-41.6)\end{array}$ & & \\
\hline Aikawa, Harrell, and Eisenberg (17) & & & & $(25.1-35.9)$ \\
\hline Miller and Wilson (2) & $\begin{array}{c}43.7 \\
(39.5-47.9)\end{array}$ & $\begin{array}{c}42.3 \\
(39.4-44.8)\end{array}$ & & \\
\hline $\begin{array}{l}\text { Moore, Edelman, Olney, James, } \\
\text { Brooks, and Wilson (18) }\end{array}$ & $\begin{array}{c}42.1 \\
(36.1-48.3)\end{array}$ & $\begin{array}{c}39.6 \\
(34.4-45.7)\end{array}$ & $\begin{array}{c}46.3 \\
(35.6-53.6)\end{array}$ & $\begin{array}{l}39.0 \\
(28.0-47.2)\end{array}$ \\
\hline Arons, Vanderlinde, and Solomon & $\begin{array}{c}42.9 \\
(40.9-44.7)\end{array}$ & $\begin{array}{c}39.7 \\
(33.8-47.8)\end{array}$ & $\begin{array}{l}51.1 \\
(47.0-54.5)\end{array}$ & $\begin{array}{c}42.4 \\
(35.5-47.9)\end{array}$ \\
\hline
\end{tabular}

* Data expressed as mean values with the range indicated in parentheses.

$\dagger$ These data are also included in the later, more detailed report of Moore et al. listed below. 
except for Aikawa, Harrell, and Eisenberg (17) whose mean value for exchangeable potassium in young adult females is considerably and unaccountably lower.

The wide range of normal data for exchangeable body sodium and potassium points out the difficulty of establishing any single value in a diseased individual as being definitely abnormal for that individual. At present, the most reliable information to be derived from exchangeable body electrolyte measurements is in patients at the beginning and end of periods of observation (such as therapeutic periods) so that changes in body composition may be interpreted rather than isolated measurements.

Indeed, in the absence of serial measurements, it may well be that the ratio of the exchangeable body sodium to exchangeable body potassium will provide more significant information in the individual patient at a given time than will isolated exchangeable electrolyte values. Thus, the mean $\mathrm{Na}_{e} / \mathrm{K}_{\mathrm{e}}$ ratios calculated from the data in Table III are $0.84 \pm 0.04$ for young adult males and $0.95 \pm 0.11$ for young adult females. This difference, if real, may be explained by the fact that males with their greater muscle mass contain relatively more exchangeable body potassium than sodium. In this respect it is interesting to note that a virilized young adult female we studied with an adrenal tumor had a "male" $\mathrm{Na}_{e} / \mathrm{K}_{e}$ ratio of 0.74 while a debilitated male with polyarteritis nodosa had an $\mathrm{Na}_{\mathrm{e}} / \mathrm{K}_{\mathrm{e}}$ ratio of 1.7 . Further studies of body sodium to potassium ratios in disease states may provide information concerning the relationship of these two ions in the body that would not be apparent from separate consideration of the exchangeable body sodium and potassium.

\section{SUMMARY}

A simple and efficient method has been presented for the simultaneous measurement of exchangeable body sodium and potassium utilizing a cationexchange resin for the separation of radioactive sodium and potassium in the serum in combination with the isotope dilution technique. Paired measurements made in normal subjects at intervals of one to two weeks and longer have indicated that the method presented gives reproducible results. Exchangeable body sodium and potas- sium measurements obtained in normal young adult subjects correspond well with data acquired by other investigators. Because of the wide range of normal values, it is suggested that body electrolyte measurements will yield the most accurate information when used in a serial fashion to study patients and that the ratio of exchangeable body sodium to exchangeable body potassium may provide a valuable index of body electrolyte composition.

\section{ACKNOWLEDGMENTS}

We should like to express our thanks to Mr. David C. Caton for his technical aid in this investigation and to Dr. Jane Worcester of the Department of Biostatistics of the Harvard School of Public Health for her help in the statistical analyses. This work has been supported in part by the Atomic Energy Commission and in part by the Medical Research and Development Board, Office of the Surgeon General, Department of the Army, under Contract No. DA-49-007-MD-155.

\section{REFERENCES}

1. Forbes, G. B., and Perley, A., Estimation of total body sodium by isotopic dilution. I. Studies on young adults. J. Clin. Invest., 1951, 30, 558.

2. Miller, H., and Wilson, G. M., The measurement of exchangeable sodium in man using the isotope ${ }^{2} \mathrm{Na}$. Clin. Sc., 1953, 12, 97.

3. Corsa, L., Jr., Olney, J. M., Jr., Steenburg, R. W., Ball, M. R., and Moore, F. D., The measurement of exchangeable potassium in man by isotope dilution. J. Clin. Invest., 1950, 29, 1280.

4. Ussing, H. H., Transport through biological membranes. Ann. Rev. of Physiol., 1953, 15, 1.

5. Ussing, H. H., Transport of ions across cellular membranes. Physiol. Rev., 1949, 29, 127.

6. Overman, R. R., Sodium, potassium and chloride alterations in disease. Physiol. Rev., 1951, 31, 285.

7. James, A. H., Brooks, L., Edelman, I. S., Olney, J. M., Jr., and Moore, F. D., Body sodium and potassium. I. The simultaneous measurement of exchangeable sodium and potassium in man by isotope dilution. In Press.

8. Arons, W. L., and Solomon, A. K., I. The separation of sodium from potassium in human blood serum by ion exchange chromatography. J. Clin. Invest., 1954, 33, 995.

9. Manery, J. F., and Bale, W. F., The penetration of radioactive sodium and phosphorus into the extraand intra-cellular phases of tissues. Am. J. Physiol., 1941, 132, 215.

10. Fenn, W. O., Noonan, T. R., Mullins, L. J., and Haege, L., The exchange of radioactive potassium 
with body potassium. Am. J. Physiol., 1941, 135, 149.

11. Solomon, A. K., and Estes, H. D., The measurement of radioactivity in solution. Rev. Scient. Instruments, 1948, 19, 47.

12. Marinelli, L. D., Quimby, E. H., and Hine, G. J., Dosage determination with radioactive isotopes. II. Practical considerations in therapy and protection. Am. J. Roentgenol., 1948, 59, 260.

13. Shohl, A. T., Mineral Metabolism. American Chemical Society Monograph Series. Reinhold Publishing Corp., New York, 1939, pp. 19-20.

14. Macy, I. G., Principal Mineral Elements in Nutrition in Handbook of Nutrition, Chicago, A.M.A., 1943, p. 108.
15. Deitrick, J. E., Whedon, G. D., and Shorr, E., Effects of immobilization upon various metabolic and physiologic functions of normal men. Am. J. Med., $1948,4,3$.

16. Freyberg, R. H., and Grant, R. L., Loss of minerals through the skin of normal humans when sweating is avoided. J. Clin. Invest., 1937, 16, 729.

17. Aikawa, J. K., Harrell, G. T., and Eisenberg, B., The exchangeable potassium content of normal women. J. Clin. Invest., 1952, 31, 367.

18. Moore, F. D., Edelman, I. S., Olney, J. M., Jr., James, A. H., Brooks, L., and Wilson, G. M., Body sodium and potassium. III. Inter-related trends in alimentary, renal, and cardiovascular disease; lack of correlation between body stores and plasma concentration. Metabolism (In Press.)

\section{SPECIAL NOTICE TO SUBSCRIBERS}

Post Offices will no longer forward the Journal when you move.

Please notify The Journal of Clinical Investigation, Business Office, 622 West 168th Street, New York 32, N. Y. at once when you have a change of address, and do not omit the zone number if there is one. 